American J. of Engineering and Applied Sciences 3 (2): 494-500, 2010

ISSN 1941-7020

(C) 2010 Science Publications

\title{
Supercritical Ethanol Liquefaction of Swine Manure for Bio-Oils Production
}

\author{
Shuangning Xiu, Abolghasem Shahbazi, Lijun Wang and Carlington W. Wallace \\ Department of Natural Resource and Environmental Design, \\ Biological Engineering Program, North Carolina A and T State University, \\ 1601 E. Market Street, Greensboro, NC, 27411
}

\begin{abstract}
Problem statement: Environmental problems associated with animal waste are the most critical challenges faced by the US intensive confinement livestock industries. There is an import and urgent need to develop an efficient way to reduce the pollution of animal waste while extracting valuable energy. Supercritical liquefaction processing of swine manure into a liquid fuel was considered as a cost-effective approach for reducing animal waste in swine farms while simultaneously increasing the farmer's income. Approach: Swine manure was converted to bio-oils by using ethanol as a solvent in an autoclave in the reaction temperature range of $240-360^{\circ} \mathrm{C}$ without any catalyst. The effect of reaction temperatures on the bio-oil yield and properties was investigated. The oil product was evaluated by Fourier Transform Infrared spectroscopy (FTIR), elemental analyses, heating values, water content analyses, ash content and solids content. Results: The experimental results show that the yield of the liquefaction products was significantly influenced by the reaction temperature. The maximum oil yield of $26.7 \%$ (of dry matter) with low content of oxygen $(11.48 \%$ ) and heating value of $33.98 \mathrm{MJ} \mathrm{kg}^{-1}$ was obtained at reaction temperature of $300^{\circ} \mathrm{C}$. A low content of carbonyl and aliphatic groups and a high aromaticity in the bio-oil were found in the bio-oils from high temperature as determined by FTIR. The elemental composition of the bio-oil samples changes with reaction temperature. However, no particular trends in the elemental composition were found within the range of reaction temperature used. Conclusion: This research proved that supercritical ethanol liquefaction was an effective way to remove oxygen and utilize carbon and hydrogen in swine manure to produce energy condensed bio-fuel. Further work is needed to optimize the bio-oil production process in terms of oil yield and oil quality.
\end{abstract}

Key words: Swine manure, supercritical liquefaction, FTIR, bio-oil

\section{INTRODUCTION}

Environmental problems associated with animal waste are one of the most critical challenges facing the livestock industry in US. An increase in swine production in recent decades has resulted in greater amounts of swine waste and associated problems with treatment. Liquid and solid animal waste generates considerable gas and odor, harbors diseases and contributes to environmental problems. Because both animal confinement facilities and urban areas are growing in size, these effects are becoming more concentrated, with the result that millions of dollars are now spent on storage, transport and treatment of these wastes. Environmental concerns and public reactions over the intensive livestock production facilities have led some state legislatures to pass new regulations on manure management. As the regulations become more stringent, livestock farming becomes more costly. Traditional treatment processes no longer satisfy environmental concerns. New technically and environmentally sound technologies are highly desirable, not only for the sustainability of livestock industry, but also for environmental protection.

Animal waste has tremendous energy potential. It can be viewed as an underutilized renewable energy resource. Within the US approximately 250 million tons of dry fecal materials are produced yearly, with an energy value comparable to wood (on a dry matter basis). If this energy could be harvested, it would be equivalent to 21 billion gallons of gasoline (ThePigSite, 2004). In the case of swine manure, an estimated 5.3 Million Tons (MT) is produced annually in the US, which could supply biomass for the production of

Corresponding Author: Shuangning Xiu, Department of Natural Resource and Environmental Design,

Biological Engineering Program, North Carolina A and T State University, 1601 E. Market Street, Greensboro, NC, 27411 Tel: 336-334-7787 Fax: 336-334-7270 
biofuels equivalent to 6.0 Million Barrels (MB) of petroleum-based fuels (USDA, 2005). The energy content of these biofuels is equivalent to $2.1 \%$ annual consumption of petroleum oil in the US.

Technological developments in the area of liquefaction conversion present new ways to turn wastes to fuel. Liquefaction was initially developed for turning coal into liquid fuels, but recently, the technique has been applied to a number of feedstocks. In a liquefaction process, carbonaceous materials are converted into a liquid product through a complex sequence of physical structure and chemical changes. The major value-added product derived from this process is tarry oil similar to crude petroleum oil that could be further upgraded to transportation fuels such as gasoline and diesel through various well-developed processes (Elliott and Oasmaa, 1991; Gevert et al., 1990).

One of the technical obstacles for the liquefaction of swine manure is its relatively low conversion rate from waste to bio-oils. Research shows that the yield of bio-oil was only $20 \%$ of the dry matter of swine manure, although most of volatile solids can be converted into bio-oil (He et al., 2000; Xiu et al., 2008; 2010). The solid and gaseous fraction consists of the remaining $70-80 \%$ of the dry matter of the manure. Therefore, it is necessary to improve the conversion efficiency and explore the uses of the solid and gaseous fractions.

Another problem associated with using water as a solvent for the liquefaction is that it produces a bio-oil with several undesired properties such as high oxygen content, high viscosity and high water content. These undesired properties have so far limited the range of bio-oil applications.

To enhance the oil yields and qualities, utilizing catalysts such as alkali metal salts (e.g., sodium carbonate), metals (e.g., iron) and organic solvents (propanol and butanol, tetralin, alcohol and acetone) instead of water have been adopted (Ogi et al., 1990; Miller et al., 1999; Cemek and Kucuk, 2001; Paulo et al., 1986). Among all the organic solvents, ethanol may be the most promising one for biomass liquefaction, because not only it is effective but it is also a renewable source that can be produced from biomass. Makabe and Ouchi (1981) have had success using supercritical alcohol rather than water to convert low rank coal into liquid oil. Tang et al. (2009) reported that supercritical ethanol $\left(\mathrm{T}=243.1^{\circ} \mathrm{C}, \mathrm{Pc}=6.37 \mathrm{MPa}\right)$ can upgrade lignin-derived oligomers in pyrolysis oil and thus reduce the tar or coke. Sub- and supercritical ethanol was also used as a reaction medium in the process of hydro- liquefaction of woody biomass ( $\mathrm{Xu}$ and Etcheverry, 2008).

In the present study, swine manure was liquefied in a supercritical solution of ethanol at a temperature range from $240-360^{\circ} \mathrm{C}$ without any catalyst. The main objective was to investigate the effect of temperature on the product distribution and characteristics of the biooil by using various analytical techniques.

\section{MATERIALS AND METHODS}

Swine manure was collected from pen floors of a swine growing facility at the $\mathrm{NC} A$ and $\mathrm{T}$ State University Research Farm. The swine manure was air dried and then ground and stored in a refrigerator below $4^{\circ} \mathrm{C}$. A sample of the swine manure was sent to Midwest Laboratories, Inc. (Omaha, Nebraska) for analysis using the method of the Association of Official Analytical Chemists (AOAC). Table 1 shows the main characteristics of the swine manure. The analysis showed that the swine manure slurry used in this study contained about $20.0 \%$ dry matter, $22.3 \%$ ash, $17.1 \%$ crude protein (Kjeldahl), $4.86 \%$ crude fat, $19.9 \%$ hemicelluloses, $15.12 \%$ cellulose and small amount of lignin, based on the weight of dry sample. The anhydrous ethanol was purposed from Fisher Scientific (Cat. A962-4).

Bio-oil production from liquefaction process: The liquefaction experiments were carried out using a floor stand 1.0 L high-pressure high-temperature stainless steel reactor whose schematic diagram is shown in Fig. 1. It is rated up to a working pressure of $34.47 \mathrm{MPa}$ and working temperature of $500^{\circ} \mathrm{C}$. A heavy-duty magnetic drive stirrer is installed for mixing. A type-J thermocouple is fitted into the reactor for direct temperature measurements of the reaction media. A standard pressure gauge is installed on the reactor head. A PID controller is used to control the temperature of the reactor.

Table 1: Characteristics of swine manure samples

\begin{tabular}{lr}
\hline Proximate analysis (\%) & 77.70 \\
Volatiles & 22.30 \\
Ash & 20.00 \\
Moisture & \\
Ultimate analysis (\%) & 33.52 \\
Carbon & 6.16 \\
Hydrogen & 2.81 \\
Nitrogen & 57.51 \\
Oxygen & \\
Component analysis (\%) & 15.12 \\
Cellulose & 19.90 \\
Hemicellulose & 0.88 \\
Lignin & 4.86 \\
Crude fat & 17.10 \\
Crude protein & 7.90 \\
Heating values $\left(\mathrm{MJ} \mathrm{kg}^{-1}\right)$ & \\
\hline
\end{tabular}


Am. J. Engg. \& Applied Sci., 3 (2): 494-500, 2010

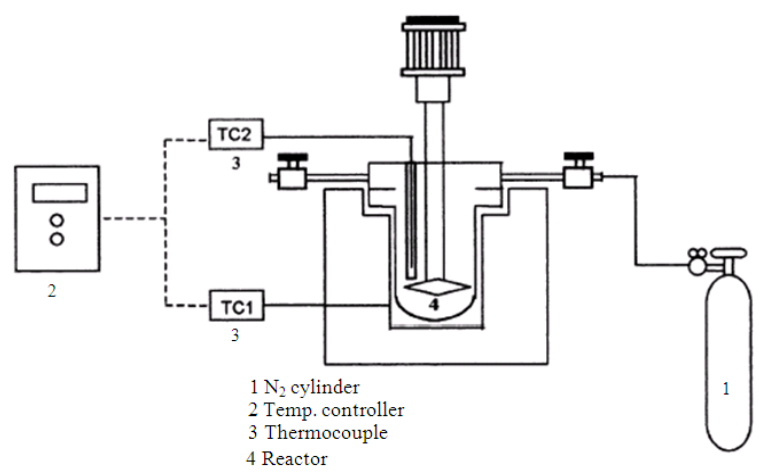

Fig. 1: Schematic diagram of the experimental reactor

In a typical liquefaction experiment, the reactor was loaded with $30 \mathrm{~g}$ of swine manure and $120 \mathrm{~g}$ ethanol. Then the reactor was purged 3 times with nitrogen to remove the air/oxygen in the reactor airspace. Agitation was set at $200 \mathrm{rpm}$ and kept constant for all experiments. The reactor was heated up and the temperature was maintained constant at the set temperature for the desired holding time. After the reaction was completed, the reactor was cooled down rapidly to room temperature by means of cooling coils, which were installed inside the reactor. The temperature and pressure were monitored and logged continuously. The heating rate and cooling rate was around $7^{\circ} \mathrm{C} \mathrm{min}^{-1}$ and $10^{\circ} \mathrm{C} \mathrm{min}^{-1}$, respectively. The gas was then released from the autoclave, reducing the pressure to atmospheric pressure. In this study, the retention time was $15 \mathrm{~min}$, the $\mathrm{N}_{2}$ initial pressure was $0.65 \mathrm{MPa}$ and no catalyst was added.

The reaction mixture consisting of oil, solid and aqueous solutions, were rinsed completely from the reactor with reagent-grade acetone and collected in a glass baker for separation. The resulting suspension was separated by filtration under vacuum through a glass fiber filter. The acetone and ethanol insoluble fraction remaining on the filter paper was then air dried at room temperature for $72 \mathrm{~h}$ to yield the solid residue. The oil was obtained from the solution by evaporating acetone at $60^{\circ} \mathrm{C}$ by a Rotavapor (Buchi rotavopor R-200/205 with vacuum pump V-700/710 and vacuum controller $\mathrm{V}-850 / 855)$. The product yield was defined as follows:

$$
\begin{aligned}
\text { Yield of oil }(\%)= & \frac{\text { Weight of oil }}{\text { Weight of dry matter }} \times 100 \\
& \text { in manure }
\end{aligned}
$$

Yield of solid residues $(\%)=$

$\frac{\text { weight of solid residues }}{\text { weight of dry matter in manure }} \times 100$

$$
\begin{aligned}
\text { Yield of }(\text { Gas }+ \text { water })= & 100 \mathrm{wt} \%-\text { yield of oil } \\
& - \text { yield of solid residues }
\end{aligned}
$$

Yield of Liquefaction $=100 \mathrm{wt} \%$ yield of solid residues

Bio-oil characterization:

Fourier Transform Infrared (FTIR) spectroscopy analysis: The functional group composition of the oil was investigated by FTIR spectroscopy using a SHIMADZU IR Prestige 21 spectrometer (MCT detector with liquid nitrogen cooling for middle IR) with Pike Miracle ATR accessory. Spectra were recorded between 400 and $4000 \mathrm{~cm}^{-1}$ with a resolution of $4 \mathrm{~cm}^{-1}$.

Elemental and heating value analysis: Elemental analyses for carbon, hydrogen, nitrogen and oxygen were determined using a PE 2400 II CHNS/O analyzer (Perkin Elmer Japan Co., Ltd.). Carbon and hydrogen mainly indicate the heating value of the oil. The atomic ratio of Hydrogen to Carbon $(\mathrm{H} / \mathrm{C})$ gives an idea of the level of saturation of the hydrocarbons in the oil. The heating value of the oil product was determined by bomb calorimeter (1108 oxygen combustion bomb, Parr. 1341 oxygen bomb calorimeter) in accordance to ASTM standard D240-02.

Physical analysis: Water content, ash and solids content: The water content was determined by Karl Fischer titration (ASTM D1744), which was performed by using Mettler ToleDo T50. ASTM Standard Method D-482 (ASTM, 2004) was adopted for use in the determination of the ash content of the oil product. In summary, the oil sample was ignited and allowed to burn completely in a furnace at $775^{\circ} \mathrm{C}$, cooled and then weighed.

The solids content refers to the ethanol-insoluble portion of the bio-oil determined by a previously published procedure (Oasmaa et al., 1997). A Buchner filtration system and preweighed Whatman filter paper were used. Bio-oil (1 g) was dissolved in $100 \mathrm{~mL}$ of ethanol and filtered. Then the filter paper was washed with ethanol until the filtrate was clear, oven-dried $\left(105^{\circ} \mathrm{C}\right)$ for $1 \mathrm{~h}$ and stored in a desiccator prior to reweighing. The weight of the ethanol-insoluble solids divided by the weight of the bio-oil sample is the fractional solids content.

\section{RESULTS}

The effect of reaction temperature on products distribution: The effect of reaction temperature on the product yield and liquefaction yield of swine manure in 
Am. J. Engg. \& Applied Sci., 3 (2): 494-500, 2010

sub- and supercritical ethanol is shown in Fig. 2. Each data point in Fig. 2 represents the average two or three replications. As the temperature increased from $240-300^{\circ} \mathrm{C}$, the oil yields increased from 20.6-26.7\%. However, the oil yield decreases slightly to $23.9 \%$ when the temperature was increased to $360^{\circ} \mathrm{C}$. In contrast, the yield of (gas + water) increased significantly when the temperature increased from 300$340^{\circ} \mathrm{C}$, followed by a decrease in the yield with further increases in the reaction temperature. The reduction in both yield of oil and (gas + water) after $340^{\circ} \mathrm{C}$ reveal enhanced formation of char at higher temperature. The liquefaction yield increased gradually from $240-340^{\circ} \mathrm{C}$, followed by a decrease when the temperature increased to $360^{\circ} \mathrm{C}$. The highest yield of liquefaction of $62.77 \%$ occurred at $340^{\circ} \mathrm{C}$.

FTIR analysis of bio-oil samples: FTIR spectra of the bio-oil samples and swine manure are shown in Fig. 3. Apparently, the FTIR spectra of bio-oil samples exhibit completely different FTIR traces than the swine manure, confirming that chemical transformations occur when the swine manure undergoes supercritical liquefaction. Except for the bio-oil sample at $240^{\circ} \mathrm{C}$, the FTIR spectra of bio-oil samples obtained from different temperatures exhibited the same peaks, but these spectra differed in the relative intensity of some bands. The band centered at 1595 and $1649 \mathrm{~cm}^{-1}$ (assigned to $\mathrm{C}=\mathrm{C}$ vibrations) appeared at temperatures higher than $240^{\circ} \mathrm{C}$, revealing aromatization processes take place during the supercritical ethanol liquefaction at temperature $>240^{\circ} \mathrm{C}$.

The functional groups identified from FTIR spectrum analysis of the bio-oil samples are shown in Table 2. Interpretation of the main bands was based on Lambert et al. (1998) and Qiang et al. (2008). Peaks at 2922 and $2852 \mathrm{~cm}^{-1}$ are caused by aliphatic groups such as $-\mathrm{CH}_{2},-\mathrm{CH}_{3}$, together with $\mathrm{C}-\mathrm{H}$ deformations at 1458 and $1373 \mathrm{~cm}^{-1}$, indicating the bio-oils possess aliphatic structures. The presence of aromatic rings is also evidenced by the band at 1595 and $1514 \mathrm{~cm}^{-1}$, attributed to $\mathrm{C}=\mathrm{C}$ vibrations. Moreover, the presence of oxygen groups is suggested by the bands at 1735,1710 , $1670 \mathrm{~cm}^{-1}$ (-C=O vibrations corresponding to carbonyl, quinine, ester or carboxyl) and 1176 and $1033 \mathrm{~cm}^{-1}$ (C-O stretching vibrations in hydroxyl, ester or ether and $\mathrm{O}-\mathrm{H}$ bending vibrations).

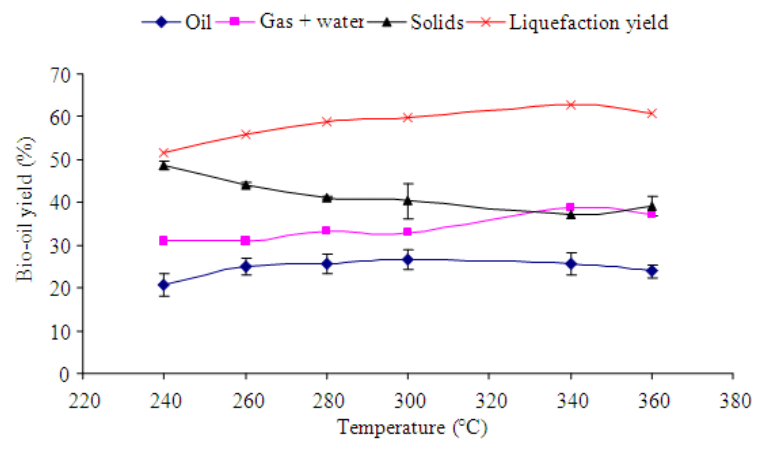

Fig. 2: The effect of temperature on bio-oil yield

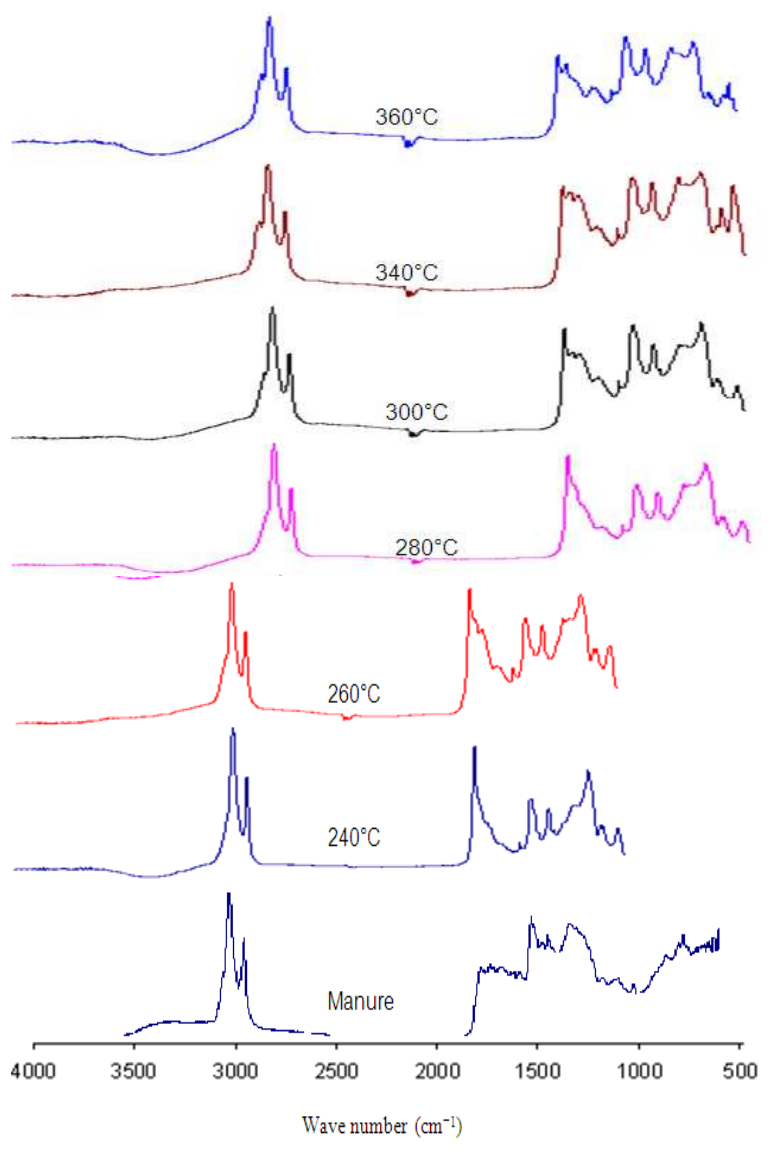

Fig. 3: FTIR spectra of oil product obtained from swine manure treated at different temperatures

Table 2: FTIR band assignments of bio-oil samples

\begin{tabular}{llll}
\hline Frequency range $\left(\mathrm{cm}^{-1}\right)$ & Position of the bands $\left(\mathrm{cm}^{-1}\right)$ & Functional group & Possible compounds present (or absent) \\
\hline $2980-2800$ & $2954,2922,2852$ & $-\mathrm{CH},-\mathrm{CH}_{2},-\mathrm{CH}_{3}$ & Aliphatic groups \\
$1850-1650$ & $1735,1710,1670$ & $\mathrm{C}=\mathrm{O}$ & Carboxylic acid, ketone, aldehydes and esters. \\
$1650-1580$ & 1595 & $\mathrm{C}=\mathrm{C}, \mathrm{C}=\mathrm{N}$ & unsaturated aliphatics, aromatics, amino acids, amides and alkenes \\
$1550-1490$ & 1514 & $\mathrm{~N}-\mathrm{H}$, aromatic C=C & Nitrogenous compounds, aromatic compounds \\
$1470-1350$ & 1458,1373 & $\mathrm{C}-\mathrm{H}$ & Alkanes and alkenes \\
$1300-950$ & 1176,1033 & $\mathrm{C}-\mathrm{O}, \mathrm{O}-\mathrm{H}$ & Ethers, alcohols, sugars \\
\hline
\end{tabular}


Am. J. Engg. \& Applied Sci., 3 (2): 494-500, 2010

Table 3: Elemental composition and heating value of bio-oil

\begin{tabular}{|c|c|c|c|c|c|c|c|}
\hline \multirow[b]{2}{*}{ Sample type } & \multicolumn{6}{|c|}{ Elemental composition (wt\%) } & \multirow{2}{*}{$\begin{array}{l}\text { Heating valu } \\
\left(\mathrm{MJ} \mathrm{kg}^{-1}\right)\end{array}$} \\
\hline & $\mathrm{C}$ & $\mathrm{H}$ & $\mathrm{N}$ & $\mathrm{O}$ & $\mathrm{H} / \mathrm{C}$ & $\mathrm{O} / \mathrm{C}$ & \\
\hline Swine manure & 33.52 & 6.16 & 2.81 & 57.51 & 2.20 & 1.29 & 7.90 \\
\hline Oil from $240^{\circ} \mathrm{C}$ & 67.47 & 7.10 & 5.48 & 19.95 & 1.26 & 0.22 & 28.16 \\
\hline Oil from $260^{\circ} \mathrm{C}$ & 69.25 & 10.97 & 3.07 & 16.71 & 1.90 & 0.18 & 31.17 \\
\hline Oil from $280^{\circ} \mathrm{C}$ & 66.60 & 7.92 & 3.39 & 22.09 & 1.43 & 0.25 & 31.43 \\
\hline Oil from $300^{\circ} \mathrm{C}$ & 73.66 & 11.61 & 3.25 & 11.48 & 1.89 & 0.12 & 33.98 \\
\hline Oil from $340^{\circ} \mathrm{C}$ & 68.15 & 10.59 & 3.92 & 17.34 & 1.86 & 0.19 & 31.93 \\
\hline Oil from $360^{\circ} \mathrm{C}$ & 69.04 & 5.62 & 5.06 & 20.28 & 0.98 & 0.22 & 33.67 \\
\hline
\end{tabular}

Table 4: Water content, ash and solids content for bio-oils from swine manure

\begin{tabular}{|c|c|c|c|c|c|c|}
\hline \multirow[b]{2}{*}{ Physical properties (wt\%) } & \multicolumn{6}{|c|}{ Bio-oil from different experimental conditions } \\
\hline & $240^{\circ} \mathrm{C}$ & $260^{\circ} \mathrm{C}$ & $280^{\circ} \mathrm{C}$ & $300^{\circ} \mathrm{C}$ & $340^{\circ} \mathrm{C}$ & $360^{\circ} \mathrm{C}$ \\
\hline Water content & 0.47 & 1.86 & 1.71 & 0.70 & 2.40 & 0.95 \\
\hline Ash content & 0.05 & 0.09 & 0.13 & 0.05 & 0.01 & 0.08 \\
\hline Solids content & 0.14 & 0.92 & 1.16 & 0.78 & 1.80 & 0.28 \\
\hline
\end{tabular}

Table 5: Elemental composition of solid char

\begin{tabular}{|c|c|c|c|c|c|c|}
\hline \multirow{2}{*}{$\begin{array}{l}\text { Elemental } \\
\text { composition, wt } \%\end{array}$} & \multicolumn{6}{|c|}{ Solid char from different experimental conditions } \\
\hline & $240^{\circ} \mathrm{C}$ & $260^{\circ} \mathrm{C}$ & $280^{\circ} \mathrm{C}$ & $300^{\circ} \mathrm{C}$ & $340^{\circ} \mathrm{C}$ & $360^{\circ} \mathrm{C}$ \\
\hline $\mathrm{C}$ & 34.25 & 33.20 & 29.17 & 30.53 & 32.06 & 34.08 \\
\hline $\mathrm{H}$ & 4.12 & 3.49 & 2.43 & 1.91 & 2.28 & 2.26 \\
\hline $\mathrm{N}$ & 2.74 & 2.74 & 2.47 & 2.49 & 2.74 & 2.70 \\
\hline $\mathrm{O}$ & 58.89 & 60.57 & 65.93 & 65.07 & 62.92 & 60.96 \\
\hline
\end{tabular}

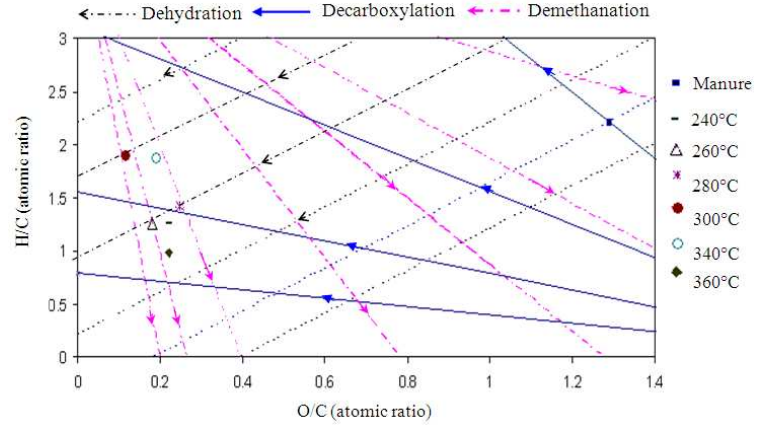

Fig. 4: $(\mathrm{H} / \mathrm{C})-(\mathrm{O} / \mathrm{C})$ Van Krevelen diagram. This shows the $(\mathrm{H} / \mathrm{C}) \mathrm{Vs}(\mathrm{O} / \mathrm{C})$ atomic ratios for

In general, the intensity of the bands at 1595 and $1514 \mathrm{~cm}^{-1}(\mathrm{C}=\mathrm{C}, \mathrm{C}=\mathrm{N})$ and 1458 and $1373 \mathrm{~cm}^{-1}(\mathrm{C}-\mathrm{H})$ become stronger with increasing reaction temperatures. Meanwhile, the intensity of the bands at 2922 and 2852 $\mathrm{cm}^{-1}\left(\mathrm{CH}_{2}, \mathrm{CH}_{3}\right), 1735 \mathrm{~cm}^{-1}(\mathrm{C}=\mathrm{O})$ and $1176 \mathrm{~cm}^{-1}(\mathrm{C}-$ $\mathrm{O})$ become weaker with increasing reaction temperatures. The rise in these bands suggests an increase in aromatic structures, nitrogenous compounds and alkenes. The weaker bands suggest a decrease in carbonyl groups $(\mathrm{COOH}$, ketone and aldehydes) as well as aliphatic groups.

Elemental analysis and heating value: The supercritical ethanol liquefaction of swine manure leads to an increase in the carbon content from $33.52 \%$ (swine manure) to 66.6-73.66\% in the bio-oil samples (Table 3). At the same time, oxygen contents reduced from $57.51 \%$ (swine manure) to $11.48-22.09 \%$ in the bio-oil samples. Some of the oxygen in the original feedstock is thought to have turned into $\mathrm{H}_{2} \mathrm{O}, \mathrm{CO}$ and $\mathrm{CO}_{2}$. The low oxygen content results in a high energy density of the bio-oils. The highest heating value of oil from swine manure was $33.98 \mathrm{MJ} \mathrm{kg}^{-1}$, which was nearly four times the heating value of swine manure, indicating that these heavy oils are useful for boiler fuel and have the potential to be used as a renewable energy resource.

It was observed that changing the temperature causes a change in the elemental content of the bio-oil samples. However, no particular trends in the elemental composition were found within the range of reaction temperatures used. The variation in the elemental composition of the materials (from swine manure to bio-oil products) was analyzed with the aid of a Van Krevelen (1950) diagram, which was plotted in Fig. 4. This graph offers the advantage of representing the elemental reactions that occur during carbonization by straight lines that describe the dehydration, decarboxylation and demethanation processes. It shows that the evolution of the $\mathrm{H} / \mathrm{C}-\mathrm{O} / \mathrm{C}$ atomic ratios from swine manure to bio-oils does not follow essentially any of the three lines, but it is in the line between the 
decarboxylation and dehydration, which suggests that the principle reactions in the supercritical ethanol liquefaction process are decarboxylation and dehydration. There is a competition between these two reactions and neither of them prevails.

Physical analysis water content, ash and solids content: Table 4 shows the water content, ash and solids of bio-oils from different test cases. Desirable physical properties of bio-oil include lower contents of water, solids and ash. Table 4 shows that the effect of the reaction temperature is not consistent for all the properties. The bio-oil obtained from $240^{\circ} \mathrm{C}$ had lowest water content $(0.47 \%)$ versus the bio-oils produced from $340^{\circ} \mathrm{C}$, which had the highest water content $(2.4 \%)$. Since there is no water in the swine manure sample and the anhydrous ethanol, it is believed that water is produced from the dehydration of carbohydrates in the manure. Ash contents ranged from $0.01-0.13 \%$. Bio-oils obtained from $340^{\circ} \mathrm{C}$ had the highest percent filterable solids $(1.8 \%)$. The solids left on the filter for bio-oil from swine manure at $340^{\circ} \mathrm{C}$ had the physical appearance of fine charcoal with dark color, while the solids obtained from other conditions had a light tan color. The solids left on the filter were acetone and ethanol insoluble solids. With $8 \mu \mathrm{m}$ filter used in these experiments, filtered bio-oil remained dark in color.

Elemental analysis of solid char: The elemental analysis of solid char was also analyzed and the data are summarized in Table 5. It is evident that the solid char have large amount of oxygen (58.89-65.93\%) and small amount of hydrogen $(2.47-2.74 \%)$.

\section{DISCUSSION}

The effect of temperature on production yields are consistent with results found by other researchers (He et al., 2000; Yin et al., 2010; Beckman and Elliott, 1985). They also found that increasing temperature helps to increase the oil yield. However, if the operating temperature was too high, there was solid char formed. This is due to the competition of two reactions involved in the liquefaction. That is, hydrolysis and repolymerization. At the initial stage, biomass is decomposed and depolymerized to small compounds by dehydration, dehydrogenation, deoxygenation and decarboxylation and these compounds may rearrange through condensation, cyclization and polymerization to form new compounds.

Russell et al. (1983) recognized the formation of aromatic compounds when cellulose was thermochemically converted in an alkali solution. They suggested that these aromatic compounds were formed by condensation or cyclization of unstable intermediate fragments, which were generated by degradation of the cellulose.

These changes observed by FTIR indicate bio-oil possess both aliphatic structures and aromatic components. The changes of intensity of the bands indicated the decrease in aliphatic structures and in increase in aromatic components with increasing reaction temperatures.

Van Krevelen diagram suggested that the principle reactions in the supercritical ethanol liquefaction process are decarboxylation and dehydration. This is consistent with the literature. Demirbas (2004) stated that the liquefaction process is very complex, which involves several kinds of reactions, such as decarboxylation, dehydration, hydrogenation and deoxygenation. It should also be noted that the bio-oil samples locations are close to each other but far away from that of manure. The biooils have a lower $\mathrm{O} / \mathrm{C}$ ratio due to decarboxylation and demethanation reactions that take place during natural coalification (Van Krevelen, 1993).

It is evident that the solid char have large amount of oxygen and small amount of hydrogen. That indicated the supercritical ethanol liquefaction process is an effective way to remove oxygen and utilization $\mathrm{C}$ and $\mathrm{H}$ in swine manure to the greatest extent. The relative large amount of carbon left in the solid char make it a good candidate for active carbon production.

\section{CONCLUSION}

Swine manure was liquefied in supercritical ethanol at reaction temperatures from $240-360^{\circ} \mathrm{C}$. Temperature played an important role on the product distribution. Increasing the temperature from 240$300^{\circ} \mathrm{C}$ was found to increase the oil yield from 20.6$26.7 \%$. However, the oil yield decreases slightly to $23.9 \%$ when the temperature was increased to $360^{\circ} \mathrm{C}$, compensating for the enhanced formation of char at higher temperatures. The highest liquefaction yield of $62.77 \%$ (of dry matter) occurred at $340^{\circ} \mathrm{C}$. The elemental composition of oil from swine manure was also strongly affected by the reaction temperature. However, no particular trends in the elemental composition were found within the range of reaction temperature used. The oil obtained from $300^{\circ} \mathrm{C}$ had the highest content of carbon $(73.66 \%)$ and hydrogen $(11.61 \%)$ and the lowest content of oxygen $(11.48 \%)$. In addition, the elemental analysis of solid char suggested that the hydrogen content in the solid char is too low to produce more bio-oil. It was evident that supercritical ethanol liquefaction was an effective way to remove oxygen and utilize carbon and hydrogen in swine manure to produce energy condensed bio-fuel. 


\section{ACKNOWLEDGEMENT}

The authors thank USDA-CSREES-Evans-Allen Project (NCX-238-5-09-130-1) for the financial support.

\section{REFERENCES}

ASTM, 2004. Annual Book of ASTM Standards. West Conshohocken, PA: American Society for Testing and Materials. http://www.astm.org/Standards/D482.htm

Beckman, D. and D.C. Elliott, 1985. Comparisons of the yields and properties of the oil products from direct thermochemical biomass liquefaction processes. Can. J. Chem. Eng., 63: 99-104. DOI: 10.1002/cjce.5450630116

Cemek, M. and M.M. Kucuk, 2001. Liquid products from verbascum stalk by supercritical fluid extraction. Energy Conver. Manage., 42: 125-130. DOI: 10.1016/S0196-8904(00)00049-2

Demirbas, A., 2004. Mechanisms of liquefaction and pyrolysis reactions of biomass. Energy Conver. Manage., 41: 633-646. DOI: 10.1016/S01968904(99)00130-2

Elliott, D.C. and A. Oasmaa, 1991. Catalytic hydrotreating of black liquor oils. Energy Fuel, 5: 102-109. DOI: 10.1021/ef00025a018

Gevert, B.S., P.B.W. Andersson, S.P. Sandqvist, S.G. Jaras and M.T. Tokarz, 1990. Hydroprocessing of directly liquefied biomass with large-pore catalysts. Energy Fuel, 4: 78-81. DOI: 10.1021/ef00019a014

He, B.J., Y. Zhang, Y. Yin, T.L. Funk and G.L. Riskowski, 2000. Operating temperature and retention time effects on the thermochemical conversion process of swine manure. Trans. ASAE, 43: 1821-1825.

Lambert, J.B., H.F. Shurvell, D. Lightner and R.G. Cooks, 1998. Organic Structural Spectroscopy. 1st Edn., Prentice Hall. Upper Saddle River, NJ., ISBN10: 0132586908, pp: 351.

Makabe, M. and K. Ouchi, 1981. Effect of pressure and temperature on the reaction of coal with alcoholalkali. Fuel, 60: 327-329. DOI: 10.1016/00162361(81)90201-5

Miller, J.E., L. Evans, A. Littlewolf and D.E. Trudell, 1999. Batch microreactor studies of lignin and lignin model compound depolymerization by bases in alcohol solvents. Fuel, 78: 1363-1366. DOI: 10.1016/S0016-2361(99)00072-1

Oasmaa, A., E. Leppamaki, P. Koponen, J. Levander and E. Tapola. 1997. Physical Characterization of Biomass-Based Pyrolysis Liquid: Application of Standard Fuel Oil Analysis. VVT Energy Publication, ISBN: 951-38-5051-X, pp: 306.
Ogi, T., S.Y. Yokoyama, T. Minowa and Y. Dote, 1990. Role of butanol solvent indirect liquefaction of wood. Sekiyu Gakkaishi, 33: 383-389.

Paulo, E.A., E.D. Sergio, J.N. Heinz and B.O. Ricardo, 1986. Catalytic wood liquefaction using a hydrogen donor solvent. Can. J. Chem. Eng., 64: 775-780. DOI: 10.1002/cjce.5450640509

Qiang, L., X.L. Yang and X.F. Zhu 2008. Analysis on chemical and physical properties of bio-oil pyrolyzed from rice husk. J. Anal. Applied Pyrol., 82: 191-198. DOI:10.1016/j.jaap.2008.03.003

Russell, J.A., R.K. Miller and P.M. Molton, 1983. Formation of aromatic compounds from condensation reactions of cellulose degradation products. Biomass, 3: 43-57. DOI: 10.1016/01444565(83)90007-0

Tang, Z., Q. Lu, Y. Zhang, X.F. Zhu and Q.X. Guo, 2009. One step bio-oil upgrading through hydrotreatment, esterification and cracking. Ind. Eng. Chem. Res., 48: 6923-6929. DOI: 10.1021/ie900108d

ThePigSite, 2004. Manure to energy-the Utah project. http://www.thepigsite.com/articles/914/manure-toenergy-the-utah-project

USDA, 2005. Agricultural Statistics 2005. USDA National Agricultural Statistics Service, Washington DC. http://www.usda.gov

Van Krevelen D.W., 1950. Graphical statistical method for the study of structure and reaction processes of coal. Fuel, 29: 269-284.

Van Krevelen D.W., 1993. Coal: Typology-PhysicsChemistry-Constitution. 3rd Edn., Elsevier, Amsterdam, ISBN: 0-444-89586-8, pp: 401.

Xiu, S.N., A. Shahbazi, V.B. Shirley and D. Chen, 2010. Hydrothermal pyrolysis of swine manure to bio-oil: Effects of operating parameters on product yields and characterization of bio-oil. J. Anal. Applied Pyrol., 88: 73-79. DOI: 10.1016/j.jaap.2010.02.011

Xiu, S.N., Y. Zhang and A. Shahbazi, 2008. Swine manure solids separation and thermochemical conversion to heavy oil. Bio Resour. J., 4: 458-470.

Xu, C.B. and T. Etcheverry, 2008. Hydro-liquefaction of woody biomass in sub- and super-critical ethanol with iron-based catalysts. Fuel, 87: 335-545. DOI:10.1016/j.fuel.2007.05.013

Yin, S.D., R. Dolan, M. Harris and Z.C. Tan, 2010. Subcritical hydrothermal liquefaction of cattle manure to bio-oil: Effects of conversion parameters on bio-oil yield and characterization of bio-oil. Bioresour. Technol., 101: 3657-3664. DOI: 10.1016/ j.biortech.2009.12.058 